\title{
ELSEVIER_RUST_1388
}

\section{Why bother with Bere? An investigation into the drivers behind the cultivation of a landrace barley}

Niamh Mahon ${ }^{\mathrm{a}, *}$

niamh.mahon@ntu.ac.uk

\section{Shawn McGuire ${ }^{b}$}

s.mcguire@uea.ac.uk

Md. Mofakkarul Islamª

mofakkarul.islam@ntu.ac.uk

aSchool of Animal, Rural and Environmental Sciences, Nottingham Trent University, Brackenhurst Campus, Southwell, Nottinghamshire, NG25 0QF, UK

bSchool of International Development, University of East Anglia, Norwich Research Park, Norwich, Norfolk, NR4 7TJ, UK

*Corresponding author

\section{Abstract}

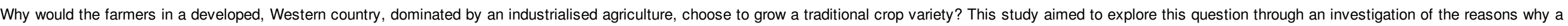

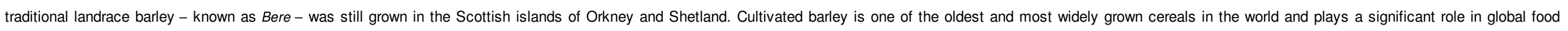

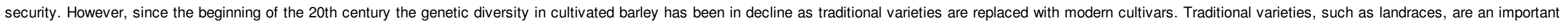

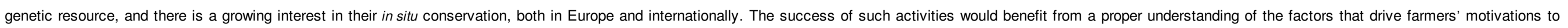

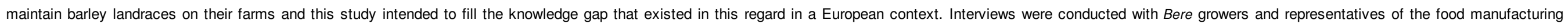

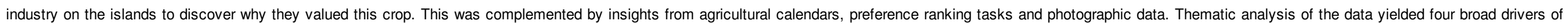

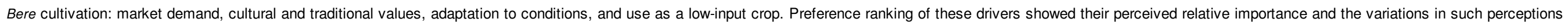
between Orkney and Shetland. The paper concludes by discussing the implications of the findings for devising more effective in situ conservation strategies for barley landraces in Europe and further afield.

Keywords: Landraces; Crop genetic resources; In situ conservation; Drivers of farmer behaviour; Bere barley; Sustainable agriculture; Agrobiodiversity; Europe

\section{Introduction}

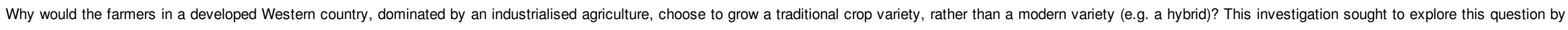

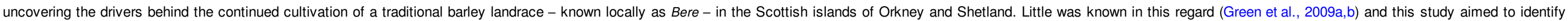
the drivers as well as the relative importance of these drivers to the individuals cultivating the crop.

\subsection{What is Bere?}

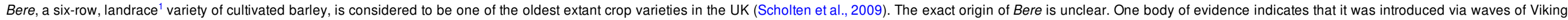

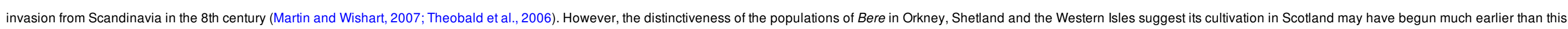


unknown.

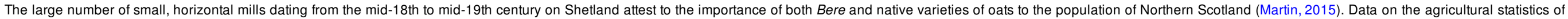




\section{ELSEVIER_RUST_1388}

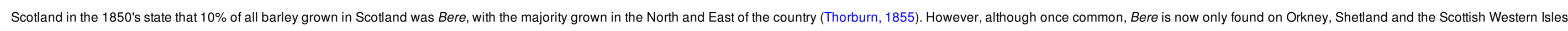

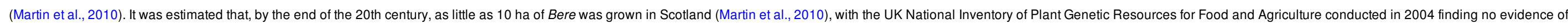

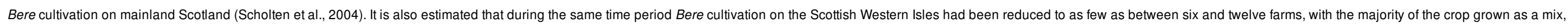
along with rye and oats. On the other hand, on Orkney and Shetland it is estimated that as few as only two farmers continued to grow Bere (Scholten et al., 2004).

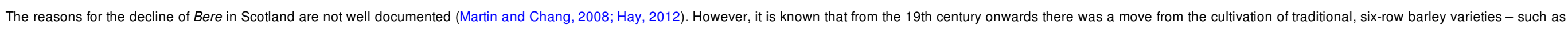

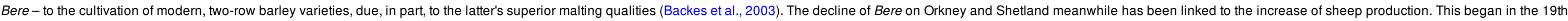
century, as wool production became an important industry, and continued into the recent past, with EU subsidies encouraging the stocking of sheep at higher densities (Martin, 2015; Science and Advice for Scottish Agriculture, 2015).

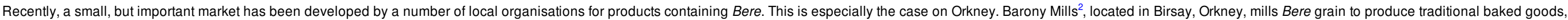

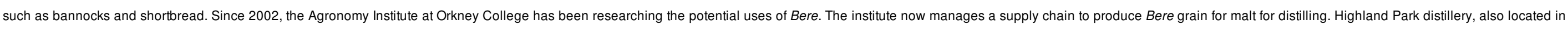

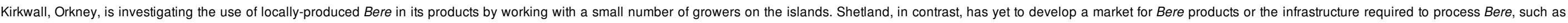
distilleries, mills, and malting facilities (Martin et al., 2009; Martin, 2015).

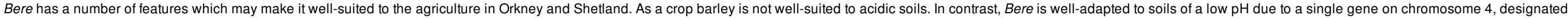

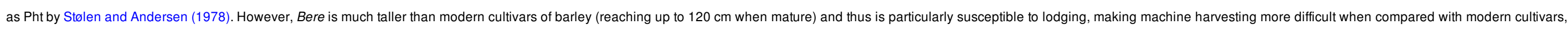

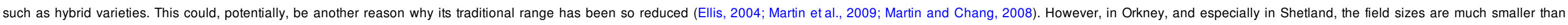
elsewhere in Britain. This means that they are much less suitable for large-scale machinery, and therefore, issues with machine-harvesting may not be so much of a drawback (Martin, 2015).

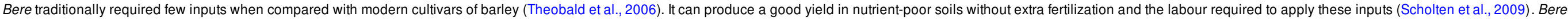
is therefore uniquely suited to "crofting ${ }^{3}$," which requires the farmer to split their time between small-scale agricultural activities and a secondary source of income.

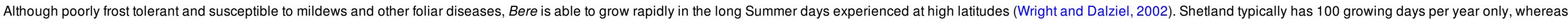

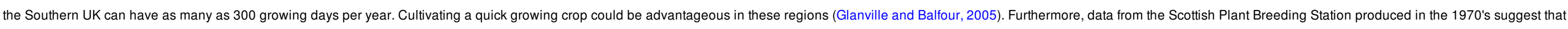

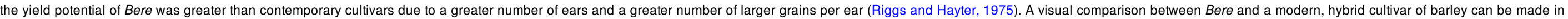
Fig. 1.

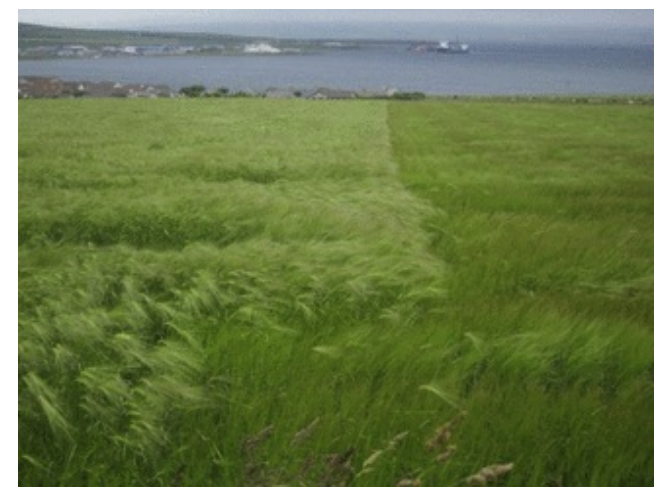

Fig. 1 Bere (right), displaying characteristic long straw and awns, and a modern cultivar of barley (left), displaying short straw and less prominent awns (photo source: this research).

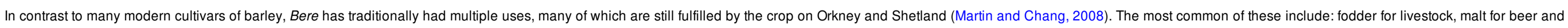

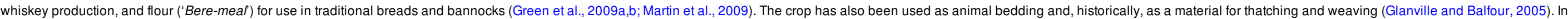

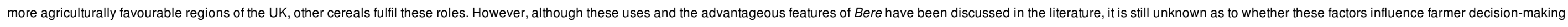
in regards to the cultivation of Bere on Orkney and Shetland. 


\section{ELSEVIER_RUST_1388}

\subsection{Why bother with Bere?}

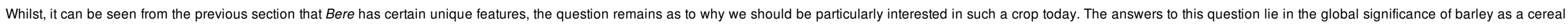
crop and the importance of barley landraces in terms of addressing some of the crucial challenges facing contemporary global agri-food systems.

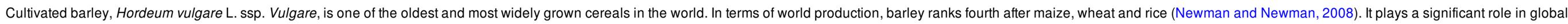

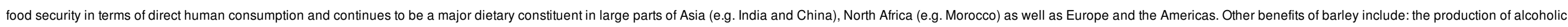

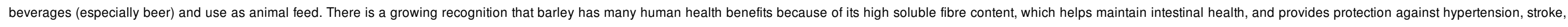
cardiovascular diseases, and type-2 diabetes (see Newman and Newman, 2008).

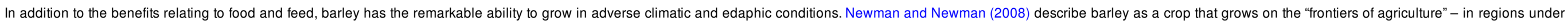

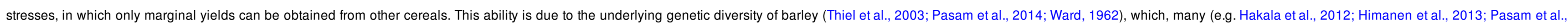

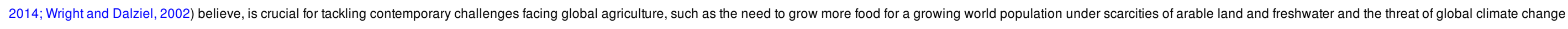
(Foresight, 2011; Godfray et al., 2010).



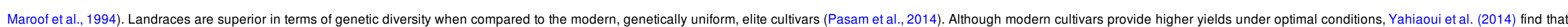

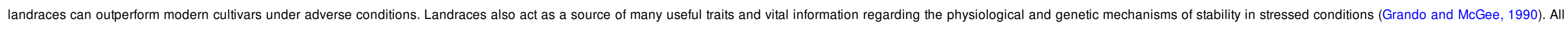

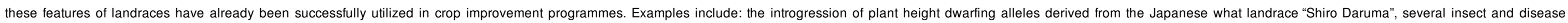

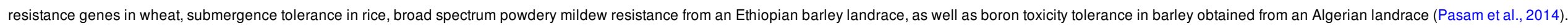

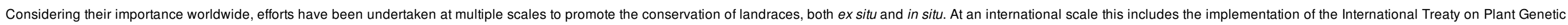

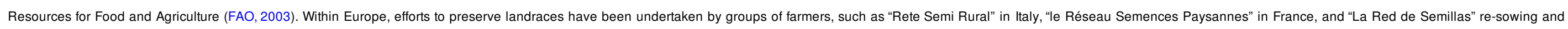

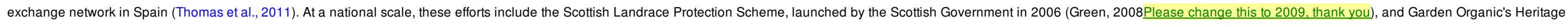

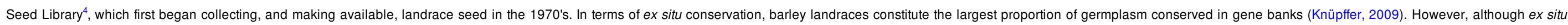

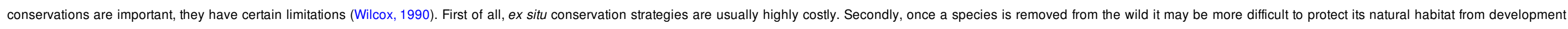

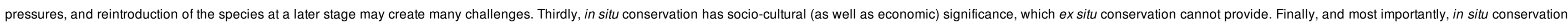
preserves the evolutionary dynamic characteristics of genetic resources, allowing gene pools to continue to generate new variants of potential value, whilst ex situ methods can adversely affect this (Wilcox, 1990).

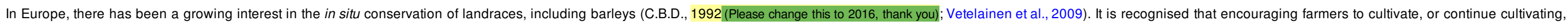
landraces is an important method of conserving these resources in the region they were developed, allowing the process of evolution and crop development to continue (Maxted et al., 1997).

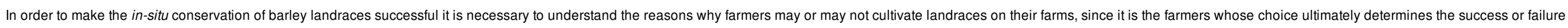

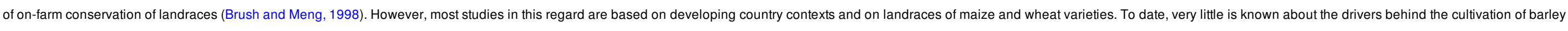

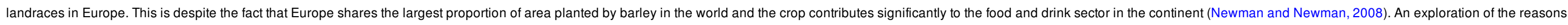
behind the continued cultivation of Bere can therefore contribute towards filing this knowledge gap.

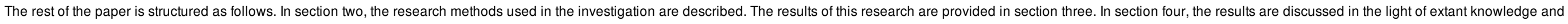
theories. Finally, in section five the key conclusions and implications of the research are drawn.

\section{Methodology}

\subsection{Analytical framework}

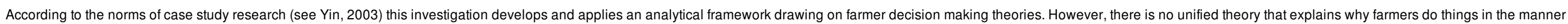




\section{ELSEVIER_RUST_1388}

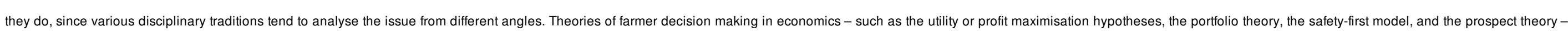

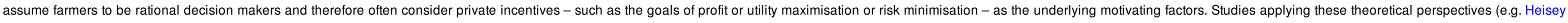

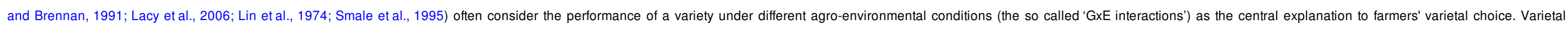

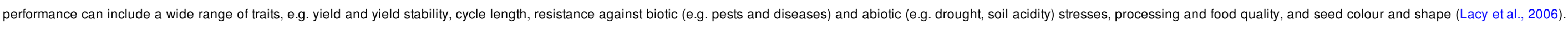
Environmental parameters may include temporal, spatial, and management dimensions, for example, seasons, years, fields, locations within fields, irrigation practices, and labour or fertilizer inputs (Lacy et al., 2006).

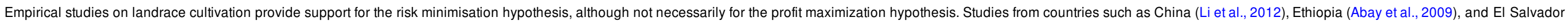

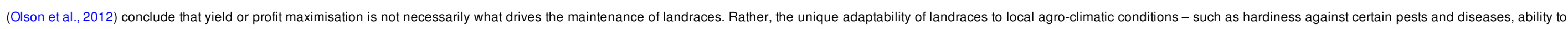

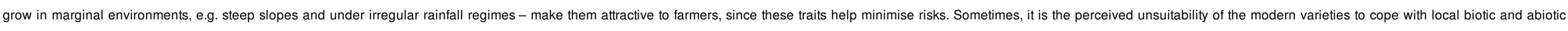

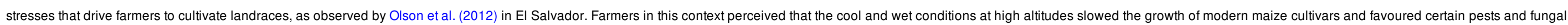

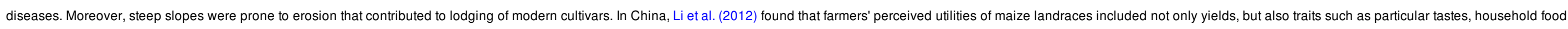

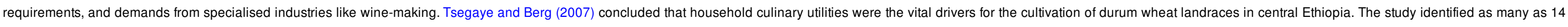

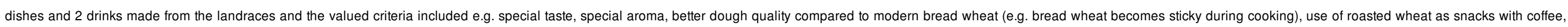
brewing local drinks for own consumption and sale, the suitability for brewing high quality malt, and higher shelf life.

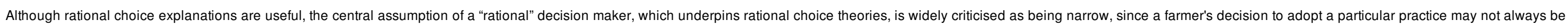

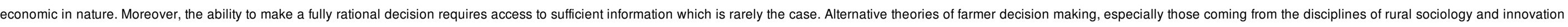
studies (Leeuwis et al., 2004; Roling and Kuiper, 1994; Rogers, 2003), take a much broader approach that consider farmer decisions to be influenced by such factors as: cultural attitudes, beliefs, norms, values as well as social networks.

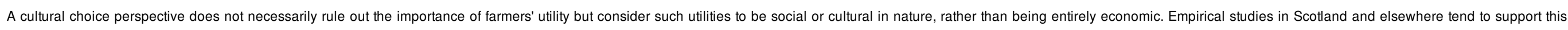

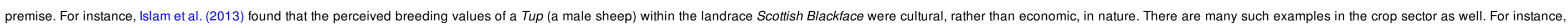

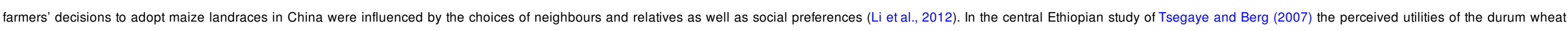

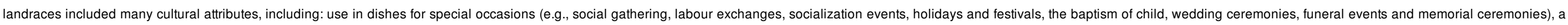
shorter cooking time, and medicinal values.

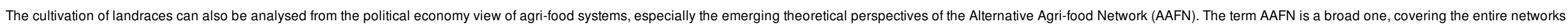

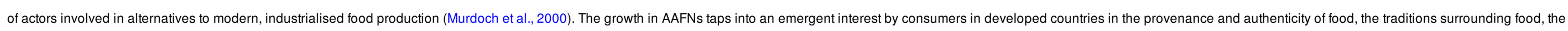



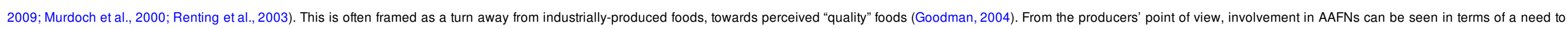

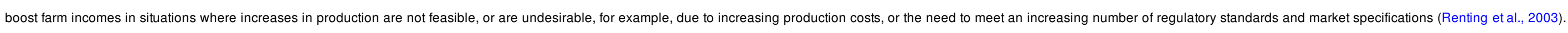

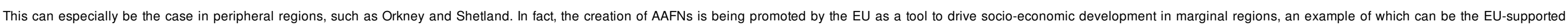
"Facilitating Alternative Agri-Food Networks" (FAAN) project5 (Ilbery and Kneafsey, 2000; LEADER, 2000; Renting et al., 2003).

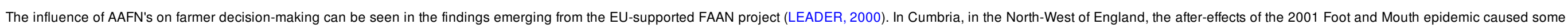



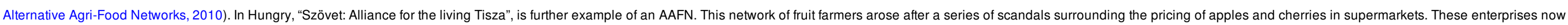
organise direct sales, via farmers markets and home deliveries of fruit, rather than interacting with intermediaries (Facilitating Alternative Agri-Food Networks, 2010).

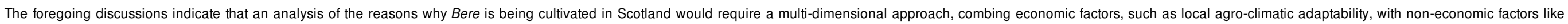

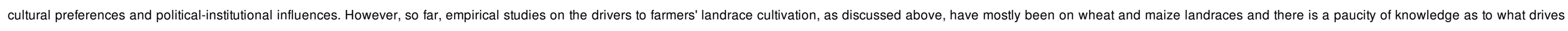
farmers' choices in regards to Barley landrace cultivation in a European context.

\subsection{Characteristics of the study locations}




\section{ELSEVIER_RUST_1388}

\subsection{Data collection}

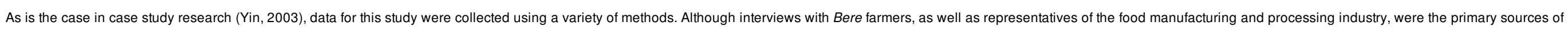
data; these were complemented by insights from agricultural calendars, preference ranking tasks, and photographic data.

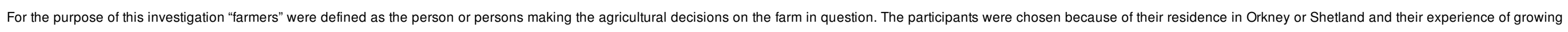

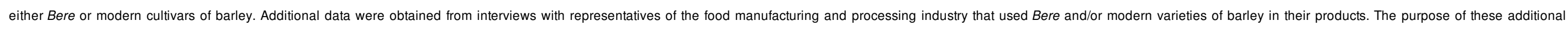

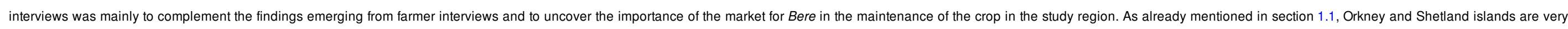

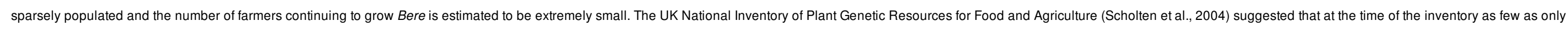


addition, one individual who was both a farmer and a food processing representative and one representative from a food processing business were interviewed.

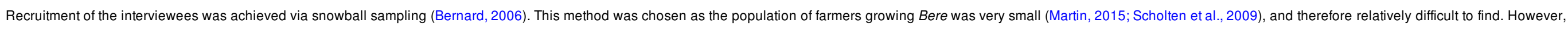

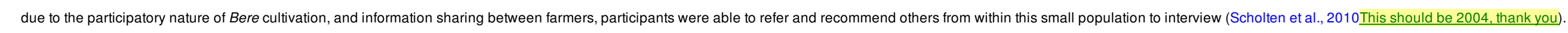

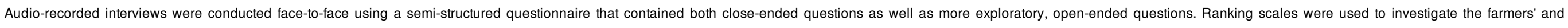

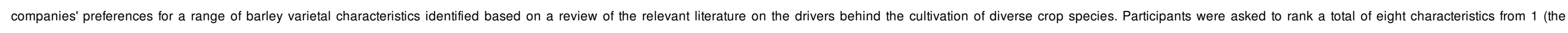

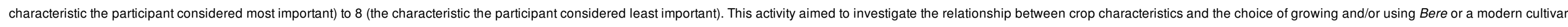



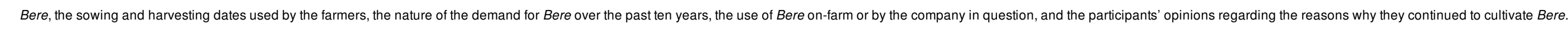

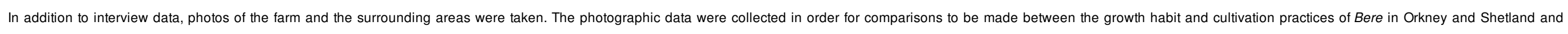
between the growth habit and cultivation practices of Bere and modern cultivars of barley. The act of collecting photographic data was often complimented by observation of the lands under cultivation, as suggested by Vogl et al. (2004).

\subsection{Data analysis}

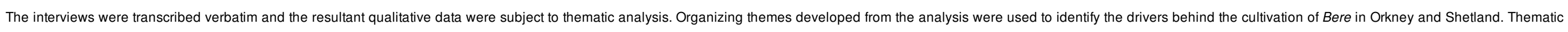

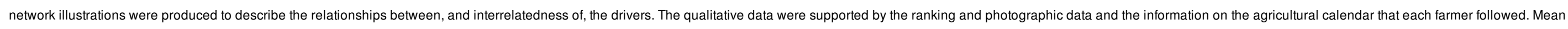

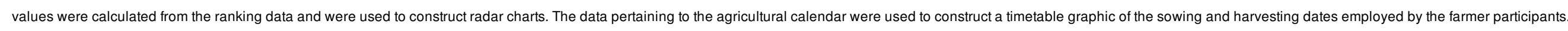

\section{Results}

\subsection{Insights from the thematic analysis}

The thematic analysis of the qualitative data yielded four organizing themes (Fig. 3): market demand, cultural and traditional values, adaptation to conditions, and use of Bere as a low input crop. 


\section{ELSEVIER_RUST_1388}

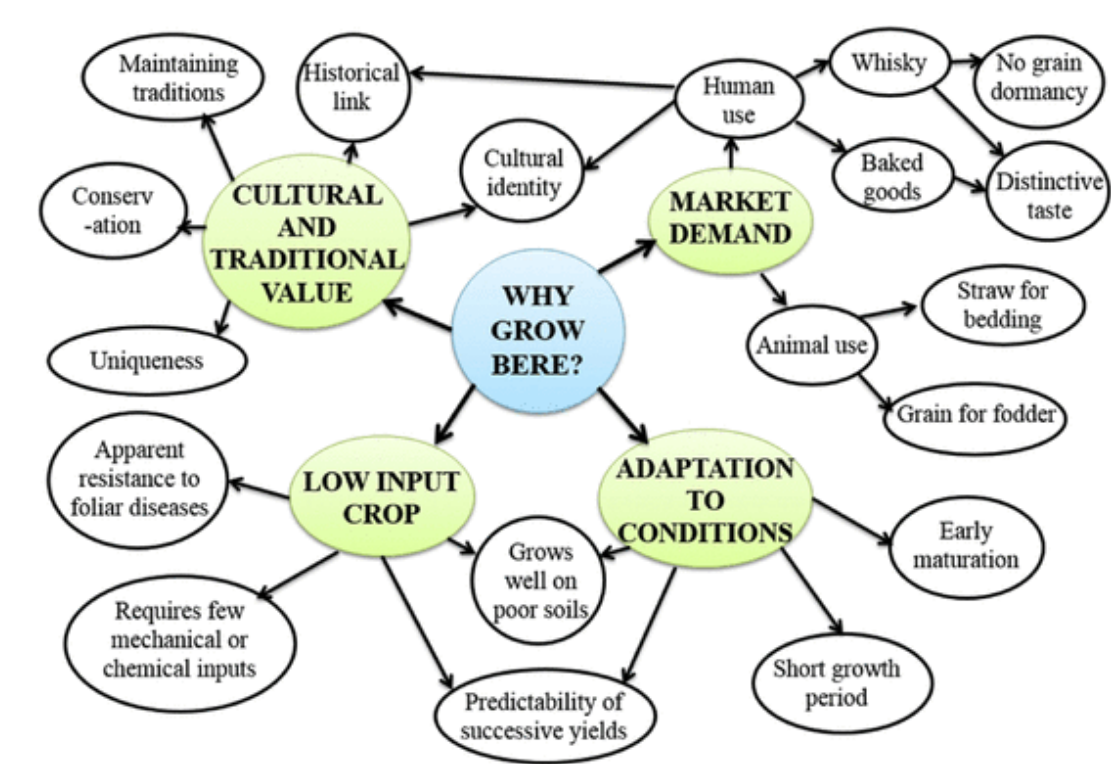

Fig. 3 Theme web developed from the analysis of interview data (source: this research).

\subsubsection{Market demand}

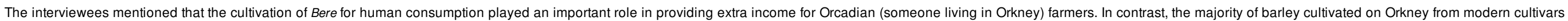
was not sold, rather it was used on-farm as fodder for livestock. Bere can therefore be seen as a type of regional cash crop. This was mentioned by a participant from Orkney:

... the market for Bere, although it's only small, is a means of some farmers getting a little bit of cash income for growing cereals.'

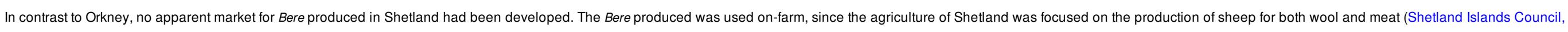
2003). However, unlike the majority of farmers in the region, those that cultivated Bere raised cattle and the crop was used mainly for cattle feed and bedding.

\subsubsection{Cultural and traditional values}

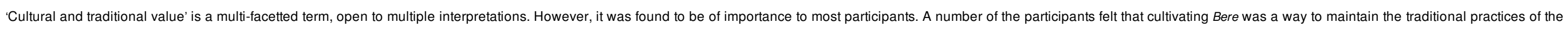
islands. A participant from Orkney, involved in cultivating the crop for milling into Bere-meal commented:

'I just wanted to keep Bere available to the public because it's an old, it's a very old, traditional grain.

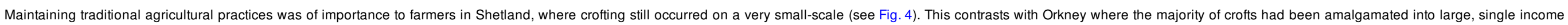
source farms, as was mentioned by a participant in Orkney who cultivated a modern variety of barley:

'It is interesting this difference between Orkney and Shetland. Farms on Orkney are much bigger, crofting isn't, there are a few people I suppose that you would consider to be crofters, but very few. Most of the farms on Orkney are quite large.' 


\section{ELSEVIER_RUST_1388}

I've seen cutting at the end of August, but usually middle of September would be what we aim for anyway. The very last of it might be in in October. But that time of year you're not wanting to be cutting barley, it could end in disaster:

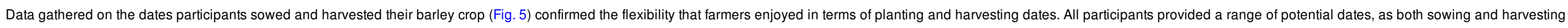

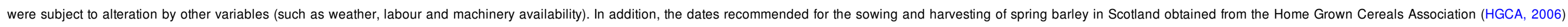
indicated that Bere was sown later than both the modern cultivar and the HGCA recommendation.

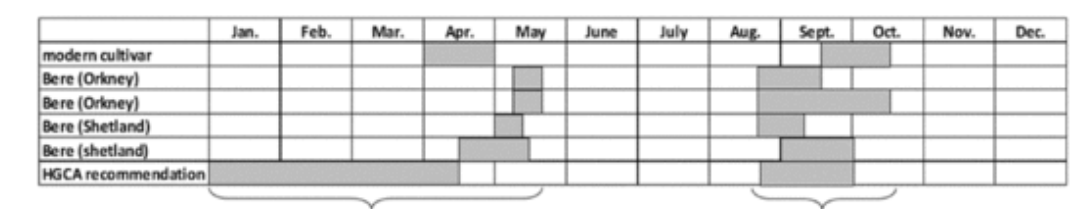

Sowing dates Harvesting dates

Fig. 5 Sowing and havesting dates followed by the farmer participants and the recommendations of the Home Grown Cereals Authority (HCGA).

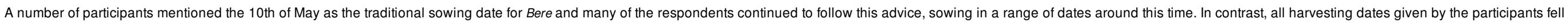

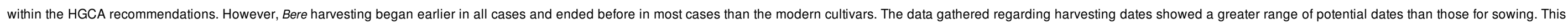
could be due to the unpredictability of the weather in late summer/early autumn, or the availability of machinery and contract workers to perform harvesting tasks.

A number of respondents mentioned the ability of Bere to grow on the acidic, poorly drained peats soils typical of Shetland, with one respondent from Shetland stating:

It (Bere) grows well on acidic, peaty soils.

Data showed that the suitability of the variety to the respondents' farm conditions seemed to be a more important consideration in Shetland than in Orkney.

\subsubsection{Bere as a low-input crop}

While explaining the reasons for Bere cultivation, many of the participants referred to a number of economic advantages, including the suitability of Bere as a low-input crop, with a participant from Orkney stating:

'I suppose it (Bere) has some really positives; one is because of this lodging problem. Lodging can be made worse if you put a lot of fertilizers on, so... (we) don't put much nitrogen fertilizer on. So, the farmer costs in terms of nitrogen are lower.'

It was unclear whether reducing fertilizer use resulted in any observable yield penalty. However, it is likely that any yield penalty was offset by the costs saved in purchasing and applying fertilizers and preventing crop lodging.

Furthermore, Bere was seen as a crop well-suited to organic agricultural systems, producing a reliable yield under a low input regime. One participant on Orkney stated:

'It (Bere) was suited to the organic system with low inputs on poorer ground.'

The apparent resistance of Bere to foliar diseases was also mentioned, with one participant from Orkney commenting:

'It (Bere) doesn't seem to get the leaf diseases, there are a couple of leaf diseases, one of them is called Rhynchosporium ${ }^{6}$ which does give concern and it doesn't seem to get that.

\subsection{Insights from barley varietal preference ranking}

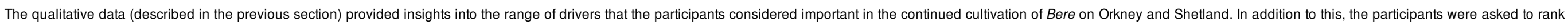
these drivers according to perceived importance. The data obtained from this exercise were tabulated, mean values calculated, and the results plotted on a radar chart (Fig. 6). 


\section{ELSEVIER_RUST_1388}

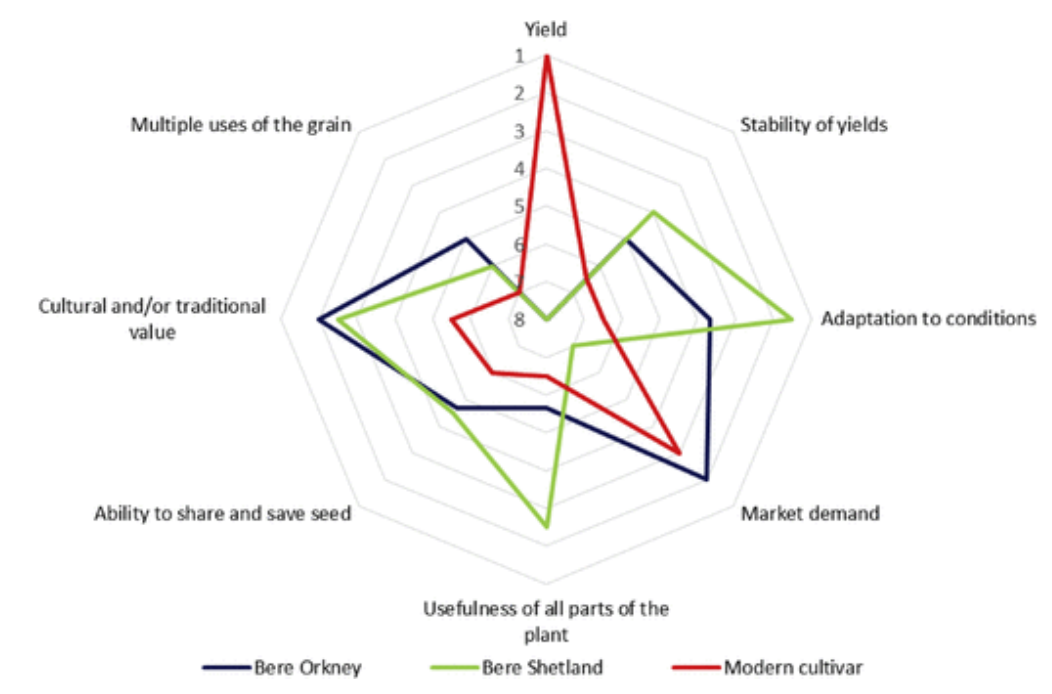

Fig. 6 Barley variety ranking chart, mean results $(1=$ most important characteristic, $8=$ least important characteristic).

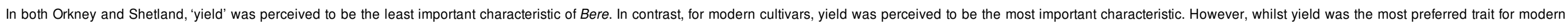
cultivars, yield stability was not. On this trait Bere was perceived as a better alternative. Bere also received higher scores than modern cultivars when considering the 'multiple uses of the grain.

'Adaptation to conditions' was the most important characteristic for Bere growers in Shetland. However, this trait was ascribed a lower value in Orkney. The modern cultivars of barley received the lowest score on this trait.

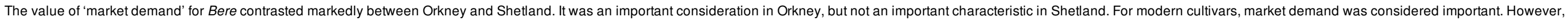
on Orkney the value of 'market demand' for modern cultivars was valued less than the 'market demand' for Bere.

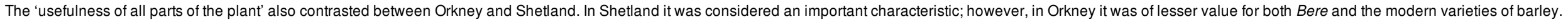

For Bere, the 'ability to share and save seed' was valued to a similar degree in both Orkney and Shetland. For the modern cultivars, this characteristic was valued far less.


be far less important.

\section{Discussion}

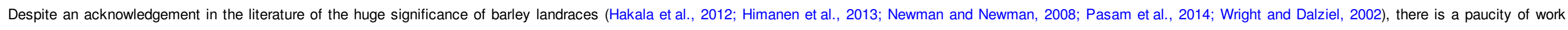

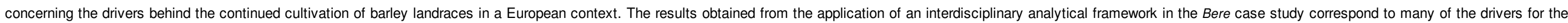
cultivation of other landraces, as reported in the literature (Abay et al., 2009; Leeuwis et al., 2004; Li et al., 2012; Olson et al., 2012; Roling and Kuiper, 1994; Rogers, 2003; Tsegaye and Berg, 2007).

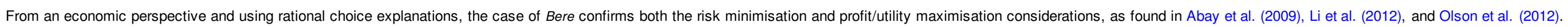

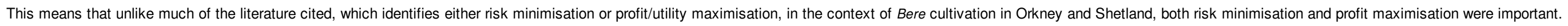

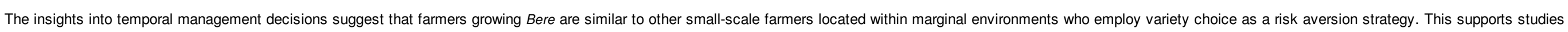

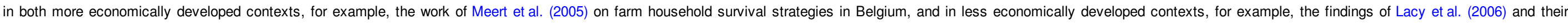

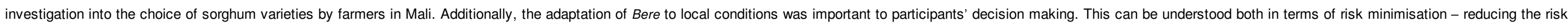

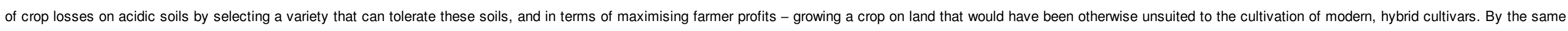

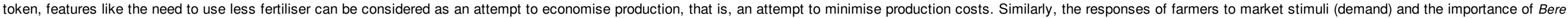




\section{ELSEVIER_RUST_1388}

as a low-input crop can be interpreted as some of the profit maximisation drivers.

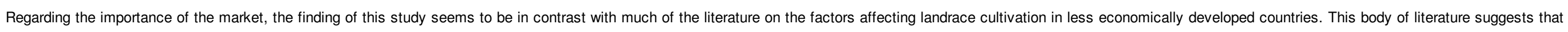

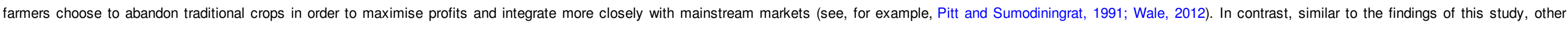

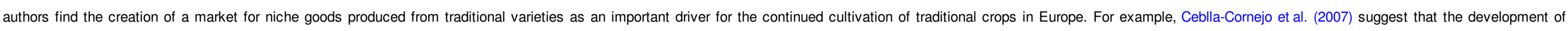



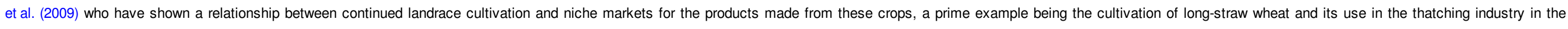

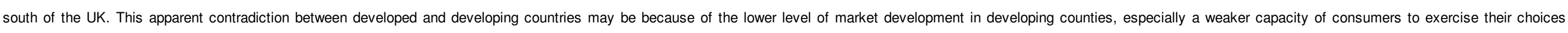

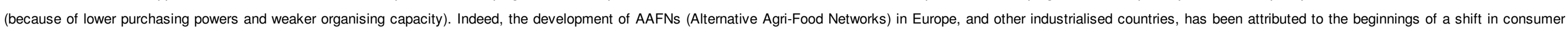

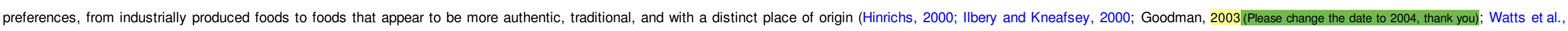
2005; Higgins et al., 2008). Such an example of consumer power can be rarely noticed in developing countries.

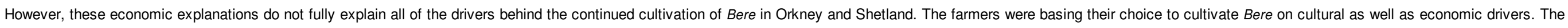

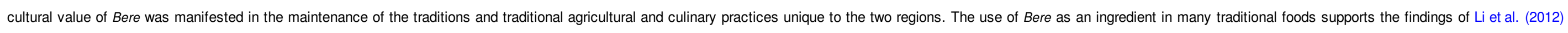

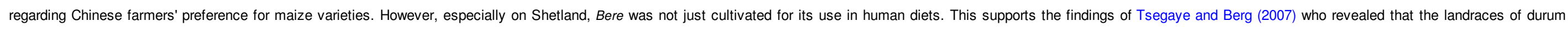

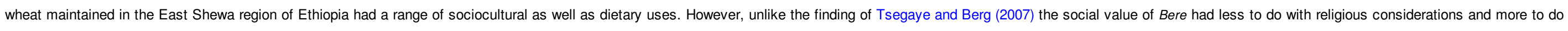
with both Orkney and Shetland's unique history when compared with the rest of the UK.

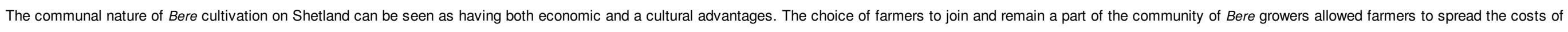

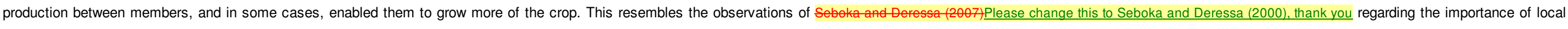
cultural institutions in maintaining the exchange systems of traditional crop varieties in Ethiopia.

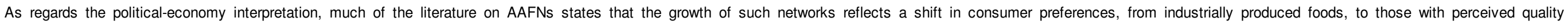

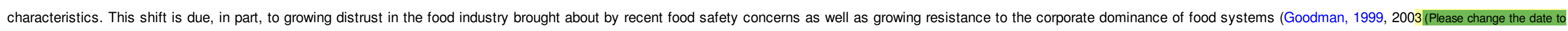

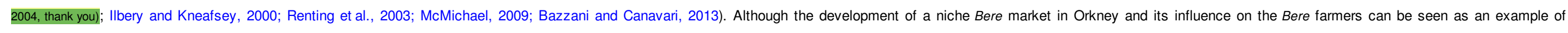

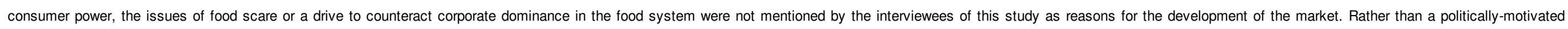



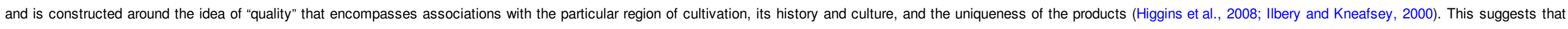
although Bere is valued on Orkney and Shetland, it would be far less valuable in other regions which do not have these historical and cultural ties to the crop.

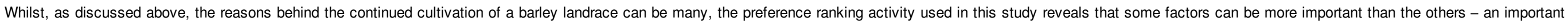

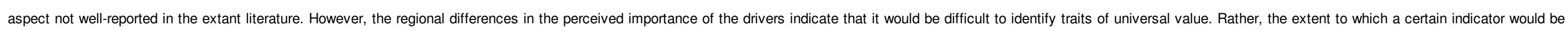

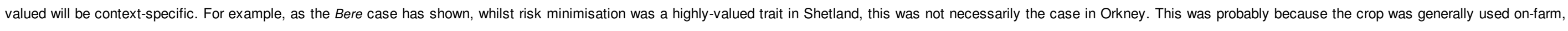

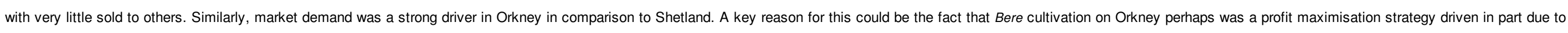

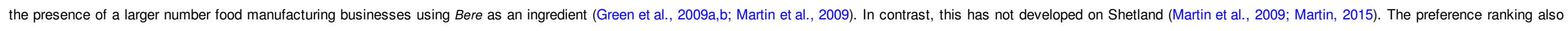

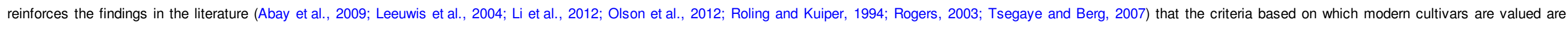
different from the criteria based on which landraces are valued.

\section{Conclusions}

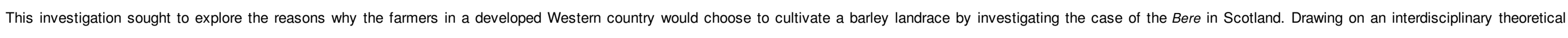

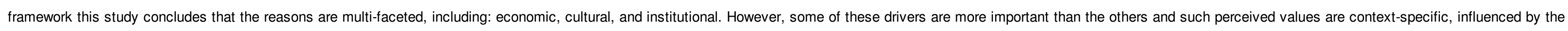

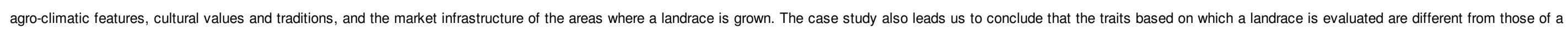




\section{ELSEVIER_RUST_1388}

http:/ldx.doi.org/10.1016/j.envi.2011.03.005.


Networks: Stakeholder Perspectives on Research Needs' Undertaken by the FAAN partners, with funding from the European Union's Seventh Framework Programme: Theme 'Science in Society.'.

FAO, International Treaty on Plant Genetic Resources for Food and Agriculture, 2003, Food and Agriculture Organization of the United Nations; Rome, Italy http://www.planttreaty.org/sites/default/files/edm1_full_en.pdf.

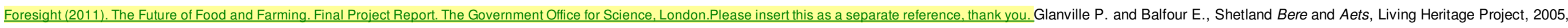
Shetland Organic Producers Group; Tingwall, Shetland.

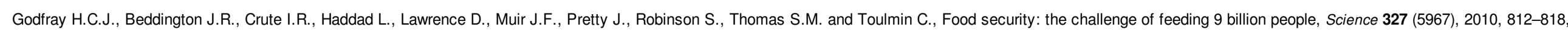
http://dx.doi.org/10.1126/science.1185383.

Goodman D., Agro-food studies in the age of ecology: nature, corporeality, bio=politics, Sociol. Rural. 39, 1999, 17-38.

Goodman D., Rural Europe redux? Reflections on alternative agro-food networks and paradigm change, Sociol. Rural. 44 (1), 2004.

Grando S. and McGee R.J., Utilization of Barley Landraces in a Breeding Program, Biotic Stresses of Barley in Arid and Semi-Arid Environments, Big Sky, Montana1990.

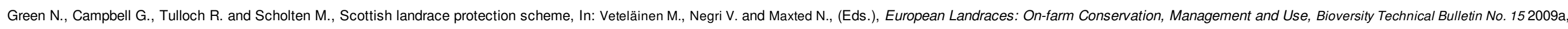
Bioversity International; Rome, Italy, 172-181.

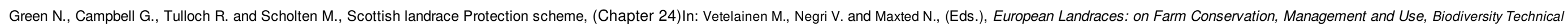
Bulletin Number 15 2009b, Bioversity International; Rome.

Hakala Jauhiainen, Himanen Rötter, Salo and Kahiluoto, Sensitivity of barley varieties to weather in Finland, Clim. Change Agric. 150 (2), 2012, 145-160 http://dx.doi.org/10.1017/S0021859611000694.

Harlan d,-, Ourvanishing genetie resourees, Science 188 (4188),7975, 618-621, http.:1/dx.doi.org/10.1126/seienee.188.4188.617.

Hay R., Bere barley: rediscovering a Scottish staple, Rev. Scott. Cult. 24, 2012, 126-139.

Heisey P.W. and Brennan J.P., An analytical model of farmers' demand for replacement seed, Am. J. Agric. Econ. 73 (4), 1991, $1044-1052$.

HGCA, Topic Sheet No. 42, Rhynchosporium Control Programmes, 2000, Home Grown Cereals Association, Research and Development, Caledonia House; London, UK

HGCA, In: Edwards C. and Dodgson G., (Eds.), The Barley Growth Guide, Winter 2005-2006, 2006, Home Grown Cereals Association, Caledonia House; London, UK.

Higgins V., Dibden J. and Cocklin C., Building alternative agri-food networks: certification, embeddedness and agri-environmental governance, J. Rural Stud. 24, $2008,15-27$.

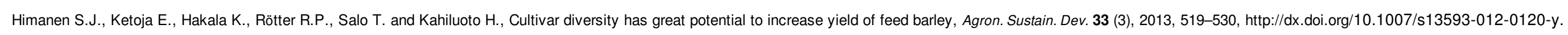

Hinrichs C.C., Embeddedness and local food systems: notes on two types of direct agricultural market, J. Rural Stud. 16, 2000, $295-303$.

Ilbery B. and Kneafsey M., Producer constructions of quality in regional speciality food production: a case study from south west England, J. Rural Stud. 16, 2000, 217-230.

Islam M.M., Renwick A., Lamprinopoulou C. and Klerkx L., Innovation in livestock genetic improvement, EuroChoices 12 (1, special issue: Innovation in Agri-food), $2013,42-47$.

Jones M., Playing the indigenous card? The Shetland and Orkney Udal Law Group and indigenous rights, Geojournal 77, 2012, 765-775.

Knüpffer H., Triticeae genetic resources in ex situ genebank collections, In: Genetics and Genomics of the Triticeae (31-79), 2009, Springer US.

Lacy S.M., Cleveland D.A. and Soleri D., Farmer choice of sorghum varieties in southern Mali, Hum. Ecol. 34 (3), 2006, 331-353, http://dx.doi.org/10.1007/s10745-006-9021-5. 


\section{ELSEVIER_RUST_1388}

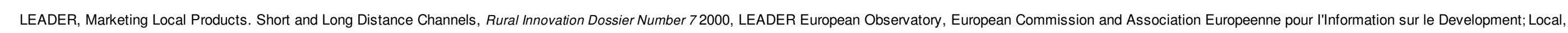
Brussels.

Leeuwis C., Leeuwis C. and Ban A., Communication for Rural Innovation, 2004, Blackwell Publishers.

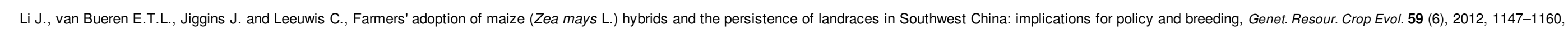
http://dx.doi.org/10.1007/s10722-011-9750-1.

Lin W., Dean G.W. and Moore C.V., An empirical test of utility vs. profit maximization in agricultural production, Am. J. Agric. Econ. 56 (3), 1974, $497-508$.

Love B. and Spaner D., Agrobiodiversity: its value, measurement and conservation in the context of sustainable agriculture, J. Sustain. Agric. 31 (2), 2007, 53-82, http://dx.doi.org/10.1300/J064v31n02_05.

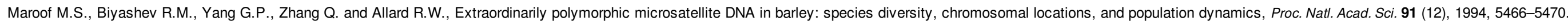

Marsden T., Banks J. and Bristow G., Food supply chain approaches: exploring their role in rural development, Sociol. Rural. 40 (4), $2000,424-438$.

Martin P., Review of Cereal Growing in Shetland, A Report Published by Orkney College (University of the Highlands and Islands), April 20152015.

Martin P. and Chang X., Bere Whisky - rediscovering the spirit of and old barley, Brew. Distill. Int. 4 (6), 2008, 41-43.

Martin P.J. and Wishart J., Bere and beer, growing old cereals on Northern Islands, Brew. Distill. Int. 3 (6), 2007, 29.

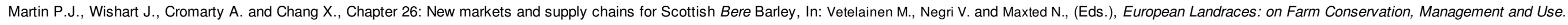
Biodiversity Technical Bulletin Number 15, 2009, Biodiversity International; Rome.

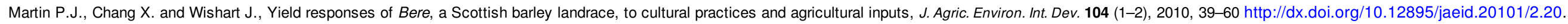

Maxted N., Ford-Lloyd B. and Hawkes J., Plant Genetic Conservation the In Situ Approach, 1997, Chapman and Hall.

McMichael P., A food regime genealogy, J. Peasant Stud. 36 (1), 2009, 139-169.

Meert H., Van Huylenbroeck G., Vernimmen T., Bourgeois M. and van Hecke E., Farm household survival strategies and diversification on marginal farms, J. Rural Stud. $21,2005,81-97$.

Murdoch J., Marsden T.K. and Banks J., Quality, nature, and embeddness: some theoretical considerations in the context of the food sector, Econ. Geogr. 76 (2), $2000,107-125$.

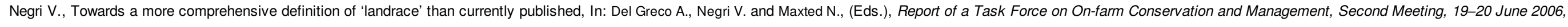
Stegelitz, Germany, 2007, Bioversity International; Rome, Italy, 20.

Newman R.K. and Newman C.W., Barley for Food and Health: Science, Technology and Products, 2008, John Wiley and Sons; Hoboken N.J.

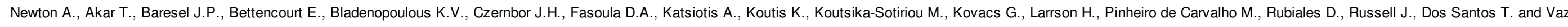
Patto M.C., Cereal landraces for sustainable agriculture: a review, Agron. Sustain. Dev. 30, 2010, 237-269, http://dx.doi.org/10.1051/agro/2009032.

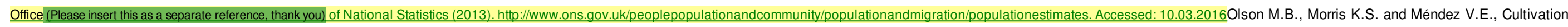
of maize landraces by small-scale shade coffee farmers in western El Salvador, Agric. Syst. 111, 2012, 63-74, http://dx.doi.org/10.1016/j.agsy.2012.05.005.

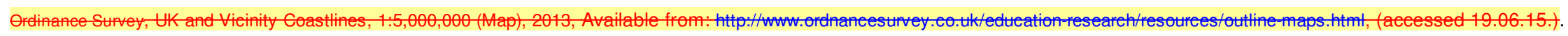

Orkney Economic Review, Orkney Islands Council, Kirwall, 2012-13.

Osman A-and Chable V., Inventery of initiatives on seeds of landraees in Europe, d. Agric. Environ. Int. Dov. 103 (7-2),-2009, 95-730 http://dx.dei.org/10.12895/jaeid.20091/2.27.

Pakeman R.J., Huband S., Kriel A. and Lewis R., Changes in the management of Scottish Machair Communities and associated habitats from the 1970's to the present, Scott. Geogr. J. 127 (4), 2011 , 267-287. 


\section{ELSEVIER_RUST_1388}

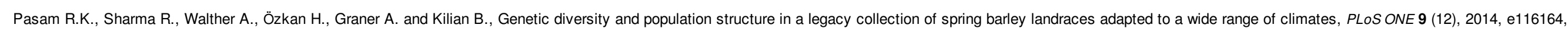
http://dx.doi.org/10.1371/journal.pone.0116164.

Pitt M. and Sumodiningrat G., Risk, schooling and the choice of seed technology in developing countries: a meta-profit function approach, Int. Econ. Rev. 32 (2), 1991, $457-473$.

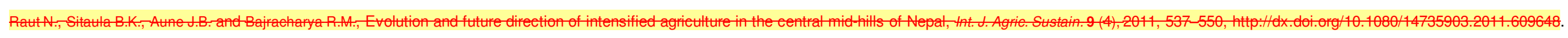

Renting H., Marsden T. and Banks J., Understanding alternative food networks: exploring the roleof short food supply chains in rural development, Environ. Plan. A 35, $2003,393-411$.

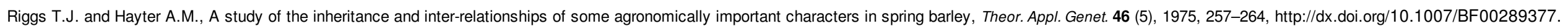

Rogers E.M., Diffusion of Innovations, 2003, Simon and Schuster; London.

Roling N.G. and Kuiper D., Basisboek voorlichtingskunde, Boom, 19941994.

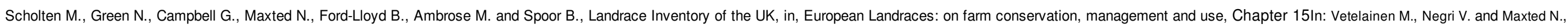
(Eds.), Biodiversity Technical Bulletin, No. 15, 2009, Bioversity International; Rome.

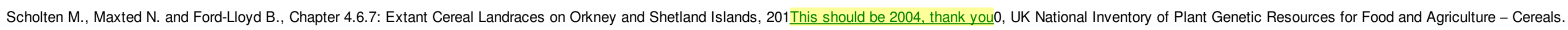
DEFRA; London.

Science and Advice for Scottish Agriculture, http://www.sasa.gov.uk/plant-variety-testing/scottish-landraces/scottish-landrace-protection-scheme-slps/bere-barley 2015.

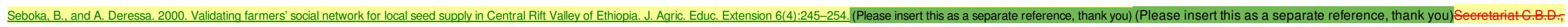
The Convention on Biologieal Diversity, 1992.

Shetland in Statistics, Economic Development Unit, 38th ed., 2011, Shetland Islands Council; Lerwick.

Shetland Islands Council, Shetland in Statistics, 30th ed., 2003, Shetland Islands Council Economic Development Unit; Lerwick, Shetland.

Smale M., Heisey P.W. and Leathers H.D., Maize of the ancestors and modern varieties: the microeconomics of high-yielding variety adoption in Malawi, Econ. Dev. Cult. Change 1995, 351-368.

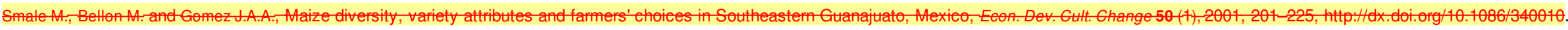

Stølen O.L.A.V. and Andersen S., Inheritance of tolerance to low soil pH in barley, Hereditas 88 (1), 1978, 101-105, http://dx.doi.org/10.1111/j.1601-5223.1978.tb01608.x.

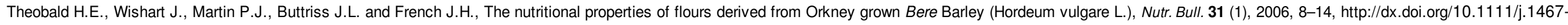
3010.2006.00528.x

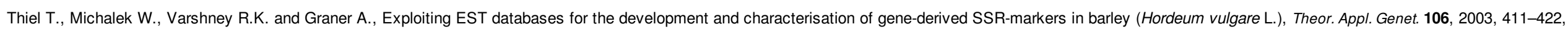
http://dx.doi.org/10.1007/s00122-002-1031-0.

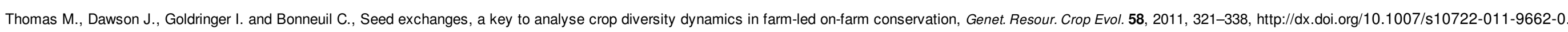
Thorburn B., Diagrams, Agricultural Statistics of Scotland for 1854, 1855, Effigham Wilson; London.

Tsegaye B. and Berg T., Utilization of durum wheat landraces in East Shewa, central Ethiopia: are home uses an incentive for on-farm conservation?, Agric. Hum. Values 24 (2), 2007, 219-230.

Vergurnst J., Farming and the nature of landscape: stasis and movement in a regional landscape tradition, Landsc. Res. 37 (2), 2012, 173-190.

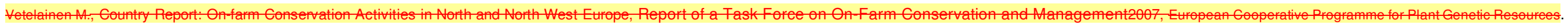


